posed.

Oxidize $1 \mathrm{~m} l$ of the test solution containing $1 \sim 15$ $\mu \mathrm{g}$ of methanol by adding $0.2 \mathrm{ml}$ of $0.3 \mathrm{v} / \mathrm{v} \%$ propionaldehyde solution, $0.4 \mathrm{ml}$ of potassium permanganate solution which is prepared by dissolving $1.5 \mathrm{~g}$ of the salt in $30 \mathrm{ml}$ of water and $7.5 \mathrm{ml}$ of $85 \%$ phosphoric acid, and by diluting the mixture to $50 \mathrm{ml}$. Swirl the mixture, and keep it at the room temperature for 5 minutes. Reduce excess permanganate by adding $0.2 \mathrm{ml}$ of $0.2 \mathrm{~g} / \mathrm{ml}$ sodium sulfite solution. Swirl the mixture, and add $0.3 \mathrm{ml}$ of $0.02 \mathrm{~g} / \mathrm{ml}$ aqueous chromotropic acid solution. Slowly add $4 \mathrm{ml}$ of $75 \mathrm{v} / \mathrm{v} \%$ sulfuric acid. Heat the mixture at $80 \sim 85$ ${ }^{\circ} \mathrm{C}$ for 10 minutes with occasional swirling. After cooling to the room temperature, measure the absorbance at $575 \mathrm{~nm}$ against the reagent blank obtained by the same procedure.

The improved method has higher sensitivity in comparison with the common method, and the calibration curve follows Beer's law over the range of $1 \sim 15 \mu \mathrm{g}$ / $\mathrm{m} l$ of methanol.

(Received Aug. 21, 1972)

\section{パラロザニリン法による大気中の}

\section{メチルエステル定量}

$$
\text { 五十笔 繁* }
$$

(1972 年 10 月 16 日受理)

\section{1 緒}

化学分析法によるエステル類の定量は, 加水分解によ って生成したアルコールを定量する方法12) とエステル 類のヒドロキサム酸反応3) を用いて比色定量する方法が ある. 本法は前者のアルコールを定量することによって エステルを定量するものである，著者は，さきに4)，メ タノールのホルムアルデヒドへの睃化は, リン酸酸性の 過マンガン酸カリウム溶液ではふじゅうぶんであり, 硫 酸酸性の過マンガン酸カリウム溶液にプロピオンアルデ ヒドを添加すると酸化がより完全に進むことを報告し た. そこでメチルエステルをアルカリ溶液中で加水分解 し，メタノールをプロピオンアルデヒド共存下に過マン ガン酸カリウムで酸化して生成するホルムアルデヒドを 彷来法に彷って定量すれば，メチルエステル定量の感度 を高めることができると考え，この反応条件を検討する とともに，メチルエステル類による大気污染測定への応

\footnotetext{
* 四日市市役所公害対策課 : 三重県四日市市諏訪町
}

用を試みた・メチルエステルとして酭酸メチル，アクリ ル酸メチルを選び，加水分解時のアルカリ濃度，加水分 解速度，および捕集法などについて検討した，発色試薬 は安定性・感度にすぐれたパラロザニリン塭酸孟を用い た. 検量線は $20 〜 300 \mu \mathrm{g} / 20 \mathrm{~m} l$ の筙间でベールの法則 が成立し，モル吸光係数は $3.8 \times 10^{3}$ であ.たた。気を $30 l$ 採取した場合，0.1〜2.0 ppm のメチルエステル濃 度の測定に適する.

\section{2 試薬および装话!}

\section{1 試 薬}

吸収液: $0.5 N$ 水酸化ナトリウム溶液.

硫酸溶液：水 $50 \sim 60 \mathrm{~m} l$ に特級の濃硫酸 $15 \mathrm{~m} l$ 它振 り混ぜながら静かに加え, 泠却後, 水で $100 \mathrm{ml}$ とす る.この液は約 $5.4 N$ 硫酸となる.

過マンガン酸カリウム溶液 $(1 \mathrm{w} / \mathrm{v} \%)$ ：遌マンガン酸 カリウム $1 \mathrm{~g}$ を水に溶かし $100 \mathrm{~m} l$ とする.

プロピオンアルデヒド水溶液 $(0.3 \mathrm{v} / \mathrm{v} \%)$ : プロピオ ンアルデヒド $0.3 \mathrm{~m} l$ を水で $100 \mathrm{ml}$ とする. 使用時湔 製する。

悪硫酸ナトリウム溶液 $(2 \mathrm{w} / \mathrm{v} \%)$ ：無水曲硫酸ナトリ ウム $2 \mathrm{~g}$ を $0.05 M$ TCM 溶液に溶かし, 全量 $100 \mathrm{~m} l$ とする。使用時淍製する。

酢酸メチル標準溶液: 特級酷酸メチルを吸収湤で希釈 し, $1 \mathrm{~m} l=0.015 \mathrm{~m} l$ 酢酸メチル $\left(0^{\circ} \mathrm{C}, 760 \mathrm{mmHg}\right)=$ $48.7 \mu \mathrm{g}$ 酢酸メチルの標集溶液を淍製する。

アクリル酸メチル標準溶液：特級アクリル酸メチルを 吸収液で希勫し， $1 \mathrm{~m} l=0.015 \mathrm{ml}$ アクリル酸メチル $(0$ $\left.{ }^{\circ} \mathrm{C}, 760 \mathrm{mmHg}\right)=57.7 \mu \mathrm{g}$ アクリル酸メチルの標售溶液 芝調製する。

$0.05 M$ TCM 溶液，パラロザニリン溶液は既報 ${ }^{4)} の$ ものをそのまま使用した。

\section{2 装}

吸光度測定装置：日立分光光度計 124 型老使用儿, 淮 層長 $10 \mathrm{~mm}$ セルを用いた。

$$
\text { インピンジャー：紀本製のガラスボールフィルター付 }
$$
き.

ポンプおよび流量計：岐卓愛知帒機製エアオートサン プラー (GA-4 型) に付属のもの. 流星計月盛の落下の 補正は瑞穂計器 (株) ガスメーターを在湖てて行なった。

\section{3 足量 江}

\section{1 捕集操作}

ガラスボールフィルター付さインピンジャ一に做收淮 $20 \mathrm{ml}$ を入れ，通気速度 $0.5 \mathrm{l} / \mathrm{min}$ で大父在收引专为。

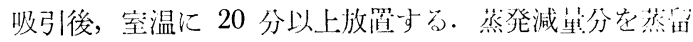
水で補正し，下記の方法で比他望望与る。

\section{2 定量操作}

被検液 $20 \mathrm{~m} l$ および標準溶液 $20 \mathrm{~m} l$ のデれぞれに， 
硫酸溶液 $2 \mathrm{~m} l$ を加え混合与る。 $1 \mathrm{w} / \mathrm{v} \%$ 過マンガン 酸カリウム溶液 $1 \mathrm{~m} l, \quad 0.3 \mathrm{v} / \mathrm{v} \%$ プロピオンアルデヒ ド溶液 $2 \mathrm{ml}$ を加之混合し, 至温に 10 分間放置する. $2 \mathrm{w} / \mathrm{v} \%$ 汧硫酸ナトリウム溶液 $1 \mathrm{~m} l$ を加光, 振り混ぜ, 過マンガン酸の色を完全に消去したのち，パラロザニリ 二溶液 $2 \mathrm{ml}$, 硫酸溶液 $1 \mathrm{~m} l$ を加光, 混和与る. 空温に 30 分放罚後, 波辰 $585 \mathrm{~nm}$ でブランク溶液に対する被

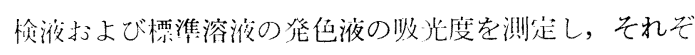
れ $A$ および $A_{\mathrm{s}}$ とする. 試料空気中のメチルエステル 嶩度 $C(\mathrm{ppm})$ は次式から求める.

$$
C(\mathrm{ppm})=\frac{15 \times v \times \frac{A}{A_{\mathrm{s}}}}{V \times \frac{273}{273+t}}
$$

ここに, $V$ は試料空父解 $(l), v$ は吸収液量 $(\mathrm{m} l), t$ は測定時の父温 $\left({ }^{\circ} \mathrm{C}\right)$.

\section{4 定量法の検融}

\section{1 加水分解条件}

種々のアルカリ濃度で 20 分開加水分解したのち, 発 色させて吸光度を測定した結果を Fig. 1 に示す.この 結果から，加水分解の目的をか权た吸収液のアルカリ溶 液を $0.5 N$ 水酸化ナトリウム溶液とした. 加水分解速度 は,メチルエステルの種類・濃度によって異なるが，本 法汇適する濃度积度では, 室温で約 20 分開でほぼ完了 する (Fig. 2).

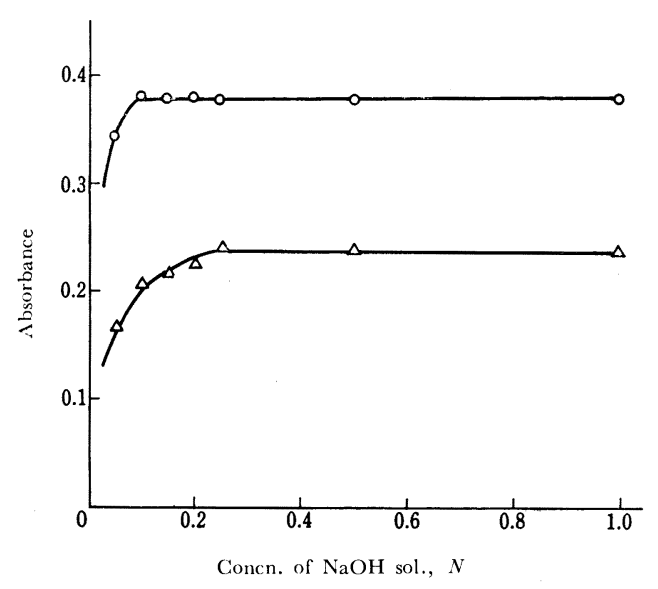

Fig. 1 Relationship between concentration of $\mathrm{NaOH}$ solution and saponification development of methyl ester at room temperature - - - Methyl acetate concentration : $140 \mu \mathrm{g} / 20 \mathrm{~m} l$; $-\triangle-$ Methyl acrylate concentration : $110 \mu \mathrm{g} / 20 \mathrm{~m} l$; Wavelength : $585 \mathrm{~nm} ;$ Temp. : $24^{\circ} \mathrm{C}$

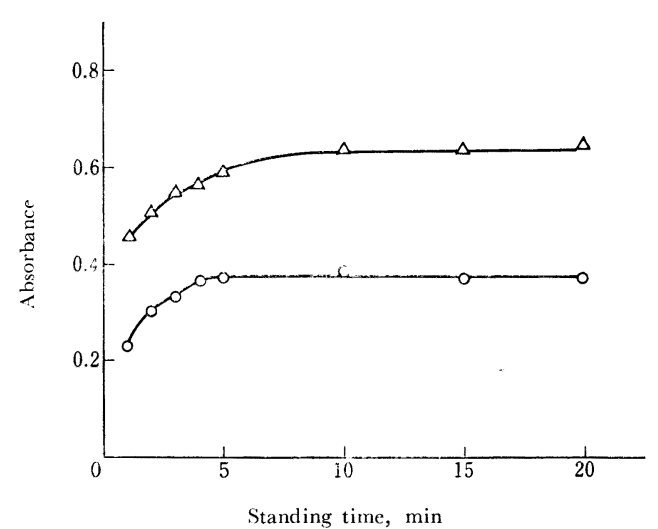

Fig. 2 Saponification velosity of methyl ester in $0.5 \mathrm{~N} \mathrm{NaOH}$ solution at room temperature -O- Methyl acetate concentration : $140 \mu \mathrm{g} / 20 \mathrm{ml}$; $-\triangle-$ Methyl acrylate concentration : $285 \mu \mathrm{g} / 20 \mathrm{ml}$; Wavelength : $585 \mathrm{~nm}$; Temp. : $24^{\circ} \mathrm{C}$

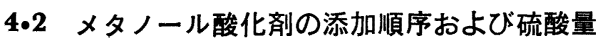

メタノールからホルムアルデヒドへの酸化は, 酸性溶 液中であることが条件の一つであるので，メチルエステ ル吸収液をあらかじめ硫酸で酸性としてから酸化剂を添 加しなければならない，その硫酸添加量は吸収液 $20 \mathrm{ml}$ に対し, 約 $5.4 N$ 液 $2 \mathrm{~m} l$ とした. $6 N$ 以上の硫酸 $2 \mathrm{~m} l$ を添加すると感度が減少し, $5.2 N$ 硫酸 $2 \mathrm{~m} l$ を 用いると, メタノール酸化後の過剩の過マンガン酸色が 亜硫酸ナトリウム溶液によって脱色しにくくなる.

\section{3 エチルエステルに対する妨害除去}

大気中のメチルエステル定量の際は, エチルエステル が共存している場合が多いので，エチルエステルに対す る感度を下げる必要がある。そのために硫酸を添加し， パラロザニリン発色時の酸性度を高めることにした5)。 この酸性度を高める試液としては, 合理的に, 本法で吸 收液を酸性化する $5.4 N$ 硫酸を用いることにした. エチ ルエステルがあまり共存していなければ，パラロザニリ ン発色時の放置時間を 60 分にするか， $5.4 N$ 硫酸の添 加量を $0.2 \sim 0.5 \mathrm{~m} l$ にしてもよいが，問题は採取する 大気中にエチルエステルがどの程度共估しているかであ る. 著者はパラロザニリン液添加後, $5.4 N$ 硫酸 $1 \mathrm{ml}$ を添加することにした。特級試薬を吸收液で適当濃度に 希䣋して求めた結果, $30 l$ 採気の場合, $40 \mathrm{ppm}$ 以下の 酥酸エチル，アクリル酸エチルならば妨害とはならなか った・な扮，硫酸添加によって，メチルエステルに対す る感度も $30 \%$ 程度減少するが, 放置時間は 30 分に短 縮され, その安定性は, 最大発色後, 室温で 25 分間は 
吸光度に変動を認めなかった、最大吸収波長は $580 \mathrm{~nm}$ から $585 \mathrm{~nm}$ に移動した。

\section{4 捕集法}

エステル類は，アルコール類に比較し 水に 溶けにく く，捕集効率がわるいので，インピンジャ一はガラスボ ールフィルター付きのものを用い，吸収液量を $20 \mathrm{ml}$ と した、酰酸メチルおよびアクリル酸メチルは，通気速度 を $0.5 \mathrm{l} / \mathrm{min}$ にしたとき， 6 回のくりかえし 実験の結 果，1本のインピンジャーで，䣷酸メチル $97.3 \%$ ，ア クリル酸メチル $96.7 \%$ の捕集効率であった. 吸収液量 を $10 \mathrm{ml}$ にしたときは，通気速度を $0.3 \mathrm{l} / \mathrm{min}$ にまで 下げなければ，95\% 以上の捕集効率は得られなかった。

終わりに，本研究を実施するにあたり，終始ご便宜な らびに協力をいただいた当課課長川合一郎氏，および 研究員水谷和一氏, 玉置泰生氏，北間 修氏，佐藤孝和 氏，一木勝弘氏，䊒谷次雄氏に深謝します。

\section{交献}

1) 竹内重二ら: 衛生化学, 9, 99 (1963).

2) 日本薬学会編：“衛生試験法注解”, p. 966(1969), (金原出版).

3）多田 治：“有害物管理のための測定法”，第 II 部, 有機編, p. 55 (1970), (労働科学研究所).

4) 五十嵐 繁: 本誌, 21, 985 (1972).

5) R. I. Veksler : Zh. Analit. Khim., 4, 14(1949).

$$
\text { 논 }
$$

Determination of methyl ester in atmosphere by the p-rosaniline method. Shigeru IGARASHI (Nuisance Countermeasure Section, Yokkaichi City Office, Suwa-cho, Yokkaichi-shi, Mie)

A sample of vapor of methyl ester is passed at a rate of $0.5 \mathrm{l} / \mathrm{min}$ through a midget impinger (with fritted glass beads attached to the tip of bubbler) containing $20 \mathrm{ml}$ of $0.5 \mathrm{~N}$ sodium hydroxide solution. The solution is allowed to stand for 20 minutes or longer at room temperature until the ester is hydrolyzed to methanol.

The recommended analytical procedure is as follows. Acidify a $20 \mathrm{~m} l$ portion of the $0.5 \mathrm{M}$ sodium hydroxide solution containing $20 \sim 300 \mu \mathrm{g}$ of methyl ester by adding $2 \mathrm{ml}$ of $2.7 \mathrm{M}$ sulfuric acid. Swirl, add $1 \mathrm{ml}$ of $0.01 \mathrm{~g} / \mathrm{ml}$ potassium permanganate solution and $2 \mathrm{ml}$ of $0.3 \%$ (by volume) propionaldehyde solution. Swirl, keep the mixture at room temperature for 10 minutes. Reduce the excess oxidizing reagent by adding $1 \mathrm{~m} l$ of $0.02 \mathrm{~g} / \mathrm{m} l$ sodium sulfite solution. Swirl, add $2 \mathrm{ml}$ of $p$-rosaniline hydrochloride solution (dissolve $0.16 \mathrm{~g}$ of the reagent completely in $24 \mathrm{ml}$ of conc. hydrochloric acid, and dilute to $100 \mathrm{ml}$ ) and $1 \mathrm{ml}$ of $2.7 \mathrm{M}$ sulfuric acid. Swirl, and let stand for 30 minutes at room temperature. Measure the absorbance at $585 \mathrm{~nm}$ against the reagent blank obtained by the same procedure.

(Received Oct. 16, 1972)

\title{
インニコチン酸-ピラゾロンを用いる シアンイオンの定量
}

\author{
石井恵一郎, 崣本武治, 山阿一彦* \\ (1972 年 10 月 16 日受理)
}

1 緒 $\overrightarrow{\bar{i}}$

ピリシンーピラゾロン法によるシアンイオンの比色定 量法は, その特異性と高感度のため, 工場排水試験法, 上水試験法など広範囲に採用されているが，ピリジンピラゾロン溶液の調製が煩雑であること, 不安定で保存 がきかないこと，悪臭有害物質のピリジンを用いること などの欠点がある. ピリジンーピラゾロン法はシアンイ オンをクロラミン Tでクロルシアンとし，ついでピリジ ンと反応させたのち，1-フェニル-3-メチル-5-ピラゾロ ンを加え，反応により生成した青色を比色する方法であ

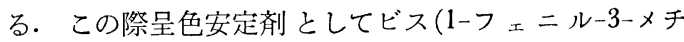
ル-5-ピラゾロン) を加えている.

著者らは種々のピリジン誘導体を検討した結果, 無臭 無害のイソニコチン酸がピリジンの代わりに使用しうる こと, また溶媒として水-ジメチルホルムアミド混合溶 媒を用いることにより試薬溶液の調製が容易になり，か つ呈色の安定化にも効果のあることを見いだし, 定量法 を確立したので報告する. 本法はシアンイオン $2.5 \mathrm{ppm}$ までベールの法則に従い，くりかえし測定精度はシアン イオン $1.0 \mathrm{ppm}$ を含む試料で $n=10$ のとき变動係数 $0.5 \%$ であった.

\section{2 実験および結果}

\section{1 装}

分光光度計は 124 形日立ダブルビーム分光光度計で $1 \mathrm{~cm}$ 石英セルを用いた。 $\mathrm{pH}$ メーターは日立一堀場 F-5 型を用いた。

\section{2 試 薬}

シアンイオン標準液：シアン化カリウム $2.52 \mathrm{~g}$ を蒸

* 和光純薬工業株式会社東京研究所 : 埼玉県川越市的 場 1633 